\title{
Effect of Dietary Fat (Soybean Oil) on Intestinal Iron Absorption in Rats
}

\author{
Minoru Hirooka, Seiji Ikeda and Naoki Kubota \\ Department of Pediatrics (Chief: Dr. M. Hirooka), \\ Akita Central Hospital, Akita
}

\begin{abstract}
Little attention has been hitherto paid to the relationship between dietary fat content and intestinal iron absorption. The present experiments were carried out to examine the influence, if any, of soybean oil on the intestinal iron absorp. tion in rats.

Female albino rats were fed on a diet consisting of polished rice powder with or without $4 \%$ vitamin mixture (basic diet) and another kind of diet consisting of the basal diet supplemented with soybean oil $(3-12 \%)$. On the last day of 2 weeks' feeding, ${ }^{59} \mathrm{FeSO}_{4}(10 \mu \mathrm{c})$ was given with a gastric tube. ${ }^{59} \mathrm{Fe}$ activity in the blood $15,30,45$ and 60 minutes after the dosage and ${ }^{59} \mathrm{Fe}$ uptake into the liver 120 minutes after the administration were measured with a well type scintillation counter.

Significantly higher activity of ${ }^{59} \mathrm{Fe}$ in both the blood and the liver was found in rats fed on the diet containing soybean oil than in those on the basic diet.

The increase of iron absorption in cases of the diet containing $6 \%$ soybean oil was almost the same as that observed with the diet containing $18 \%$ casein.
\end{abstract}

It has been reported that the intestinal iron absorption is influenced by iron storage levels of the body, erythropoietic activity, and various dietary factors. Ascorbic acid ${ }^{1-3}$ has been known to enhance iron absorption, and a dietary protein content $t^{4,5}$ of less than 15 to $18 \%$ has been considered to impair iron absorption in rats. Amino acid composition of dietary protein, ${ }^{6}$ phytate, calcium and phosphorus, ${ }^{7-11}$ pyridoxine $^{12}$ and $\mathrm{pH}$ of the intestinal content have been reported as factors participating in intestinal iron absorption. ${ }^{13}$

However, there seems to be a few suggestions ${ }^{14-12}$ concerning the role of dietary fat in iron absorption. The present study was carried out to clarify the relationship between the fat content in diet and intestinal iron absorption in rats.

\section{Material and Methods}

In the present experiments, polished rice powder was used as a basic diet for rats.

\section{Experiment $I$}

Experiment I was a preliminary examination to exclude the influence of iron

Received for Fublication, February $13,1968$. 
Twenty-two female rats of Wistar strain weighing approximately $100 \mathrm{~g}$ were divided into the following groups according to dietary compositions. Each group consisted of 5 or 6 rats.

Group 1: polished rice powder alone

Group 2: polished rice powder $+4 \%$ vitamin mixture*

Group 3: polished rice powder $+6 \%$ soybean oil $+4 \%$ vitamin mixture

Group 4: polished rice powder $+18 \%$ casein $+4 \%$ vitamin mixture

Group 5: commercial ration (Oriental solid foods for propagation of rats)**

These groups were fed on the diet mentioned above for 2 weeks and killed under ether anesthesia. Diet and water had been given ad libitum. The liver was taken out and weighed, and non-hemin iron was determined according to the method of Yoshino. ${ }^{18}$

The results were expressed as mg of iron per $\lg$ of wet weight of the liver and per total liver.

\section{Experiment $I I$}

Eighteen female rats of Wistar strain weighing approximately $110 \mathrm{~g}$ were divided into the following 3 groups. Each group consisted of 6 rats.

Group 1: polished rice powder alone

Group 2: polished rice powder $+6 \%$ soybean oil

Group 3: polished rice powder $+6 \%$ soybean oil $+4 \%$ vitamin mixture

The animals in each group were fed on respective diet for 2 weeks. On the last day of feeding, ${ }^{59} \mathrm{FeSO}_{4}(10 \mu \mathrm{c})$ was given into the stomach ${ }^{6}$ using a gastric tube, and 15, 3045 and 60 minutes after the dosage $0.04 \mathrm{ml}$ of blood samples was taken from the tails and brought into counting vials containing $2 \mathrm{ml}$ of distilled water in order to give rise to hemolysis. Each sample was then submitted to a well type scintillation counter for 5 minutes. The absorption of iron was expressed as the count in one minute.

The animals were killed 2 hours after the ${ }^{59} \mathrm{FeSO}_{4}$ introduction and the liver was excised and was digested with a mixture of concentrated sulfuric acid and nitric acid (wet digestion) The radioactivity of ${ }^{59} \mathrm{Fe}$ in the liver was counted with a well type scintillation counter. The liver ${ }^{59} \mathrm{Fe}$ uptake was expressed as cpm per one $g$ of wet liver weight or per whole liver.

\section{Experiment $I I I$}

Thirty-one female rats of Wistar strain weighing about $110 \mathrm{~g}$ were divided into

* Vitamin mixture (per $1 \mathrm{~g}$ ) contains VA 2,500 I.U., VD 200 I.U., VB $1 \mathrm{mg}, \mathrm{VB}_{2} 1.5 \mathrm{mg}$, nicotinamide $10 \mathrm{mg}, \mathrm{VB}_{6} \mathrm{l} \mathrm{mg}$, folic acid $0.5 \mathrm{mg}$, calcium pantothenate $\mathrm{VB}_{12} 1 \mu \mathrm{g}$, $\mathrm{VC}$ $37.5 \mathrm{mg}$ and $\mathrm{VE} \mathrm{l} \mathrm{mg}$.

** Oriental solid foods for propagation of rats consist of crude protein $26.55 \%$, crude fat (i.1\%, rrude ash $6.5 \%$, crude fiber $4.1 \%$; VA $1,000 \mathrm{IU}$, VD $200 \mathrm{IU}$, VE $10 \mathrm{mg}, \mathrm{VK}_{3}$ $11.2 \mathrm{mg}, V_{1}, 1.4 \mathrm{mg}, \mathrm{VB}_{2} 2.4 \mathrm{mg}, \mathrm{VB}_{5} 1.0 \mathrm{mg}$, niacin $10 \mathrm{mg}$, pantothenic acid $7.5 \mathrm{mg}$, biotin $0.02 \mathrm{mg}$, folic acid $0.15 \mathrm{mg}$, inositol $60 \mathrm{mg}$, choline $120 \mathrm{mg}, V^{2}, 0.0005 \mathrm{mg}$ and VC $20 \mathrm{mg}$ per $100 \mathrm{~g}$. 
the following 4 dietary groups.

Group 1: polished rice powder $+4 \%$ vitamin mixture

Group 2: polished rice powder $+3 \%$ soybean oil $+4 \%$ vitamin mixture

Group 3: polished rice powder $+6 \%$ soybean oil $+4 \%$ vitamin mixture

Group 4: polished rice powder $+12 \%$ soybean oil $+4 \%$ vitamin mixture

\section{Experiment IV}

Thirty-four female rats of Wistar strain weighing about $110 \mathrm{~g}$ were divided into the following 5 dietary groups.

Group 1: polished rice powder $+4 \%$ vitamin mixture

Group 2: polished rice powder $+6 \%$ soybean oil $+4 \%$ vitamin mixture

Group 3: polished rice powder $+18 \%$ casein $+4 \%$ vitamin mixture

Group 4: polished rice powder $+6 \%$ soybean oil $+18 \%$ casein $+4 \%$ vitamin mixture

Group 5: Commercial ration (Oriental solid foods for propagation of rats)

In Experiments III and IV, ${ }^{59} \mathrm{FeSO}_{4}$ was given and the radioactivity of ${ }^{59} \mathrm{Fe}$ in the peripheral blood and liver was estimated in the same way as in Experiment II.

\section{Results}

\section{Experiment $I$}

Non-hemin iron content in the liver of rats fed on each diet for 2 weeks was shown in Table 1.

TaBle 1. Non-hemin iron values in the liver of rats in Experiment $I$

\begin{tabular}{|c|c|c|c|}
\hline \multirow{2}{*}{ Dietary groups } & \multirow{2}{*}{$\begin{array}{l}\text { Number } \\
\text { of } \\
\text { rats }\end{array}$} & \multicolumn{2}{|c|}{ Non-hemin iron in liver $(\gamma)$} \\
\hline & & $\begin{array}{l}\text { Per } g \text { of liver } \\
\text { (wet weight) }\end{array}$ & Whole liver \\
\hline Polished rice powder alone & 5 & $73.6 \pm 14.4$ & $560.2 \pm 173.6$ \\
\hline $\begin{array}{l}\text { Polished rice powder }+4 \% \\
\text { vitamin mixture }\end{array}$ & 5 & $80.4 \pm 14.9$ & $491.4 \pm 79.3$ \\
\hline $\begin{array}{l}\text { Polished rice powder }+6 \% \\
\text { soybean oil }+4 \% \text { vitamin } \\
\text { mixture }\end{array}$ & 6 & $94.6 \pm 14.8$ & $638.8 \pm 175.5$ \\
\hline $\begin{array}{l}\text { Polished rice powder }+18 \% \\
\text { casein }+4 \% \text { vitamin mixture }\end{array}$ & 6 & $84.4 \pm 14.8$ & $561.5 \pm 129.0$ \\
\hline $\begin{array}{l}\text { Oriental solid foods for } \\
\text { propagation of rats }\end{array}$ & 6 & $92.5 \pm 10.1$ & $703.7 \pm 161.6$ \\
\hline
\end{tabular}

There was no significant difference in non-hemin iron content in the liver among rats fed on various kinds of diet listed in Table 1. The results indicated that iron store in the liver did not change after 2 weeks' feeding on diet which was of the same composition as used in Experiments II-IV. 


\section{Experiment $I I$}

The radioactivity of ${ }^{59} \mathrm{Fe}$ in the peripheral blood of rats in each dietary group after the introduction of ${ }^{59} \mathrm{FeSO}_{4}$ into the stomach and ${ }^{59} \mathrm{Fe}$ uptake in the liver 120 minutes after the introduction are given in Table 2 . The activity of ${ }^{59} \mathrm{Fe}$ in both the peripheral blood and the liver in the rats fed on the diets supplemented with either $6 \%$ soybean oil or $6 \%$ soybean oil and $4 \%$ vitamin mixture was higher than in rats fed on polished rice powder alone. There was a statistically significant difference in the radioactivity of ${ }^{59} \mathrm{Fe}$ in the blood 45 and 60 minutes after the introduction of ${ }^{59} \mathrm{Fe}$ between rats fed on the diet containing $6 \%$ soybean oil and those fed on polished rice powder alone, but no significant difference between rats fed on the diet containing $6 \%$ soybean oil and those fed on the diet containing $6 \%$ soybean oil $+4 \%$ vitamin mixture. ${ }^{59} \mathrm{Fe}$ uptake in the liver 120 minutes after the iron introduction was also the same, showing a significantly higher activity in the liver from dietary groups containing $6 \%$ soybean oil or $6 \%$ soybean oil $+4 \%$ vitamin mixture, than that in the dietary group of polished rice powder alone. However, there was also a significantly greater uptake of ${ }^{59} \mathrm{Fe}$ in the livers of rats fed the diet containing $6 \%$ soybean oil $+4 \%$ vitamin mixture, than that in rats fed on the diet containing $6 \%$ soybean oil alone.

TABLE 2. Radioactivity of ${ }^{59} \mathrm{Fe}$ in the peripheral blood and the liver 120 minutes after the ${ }^{59} \mathrm{FeSO}_{4}$ dosage in Experiment $\mathrm{II}$

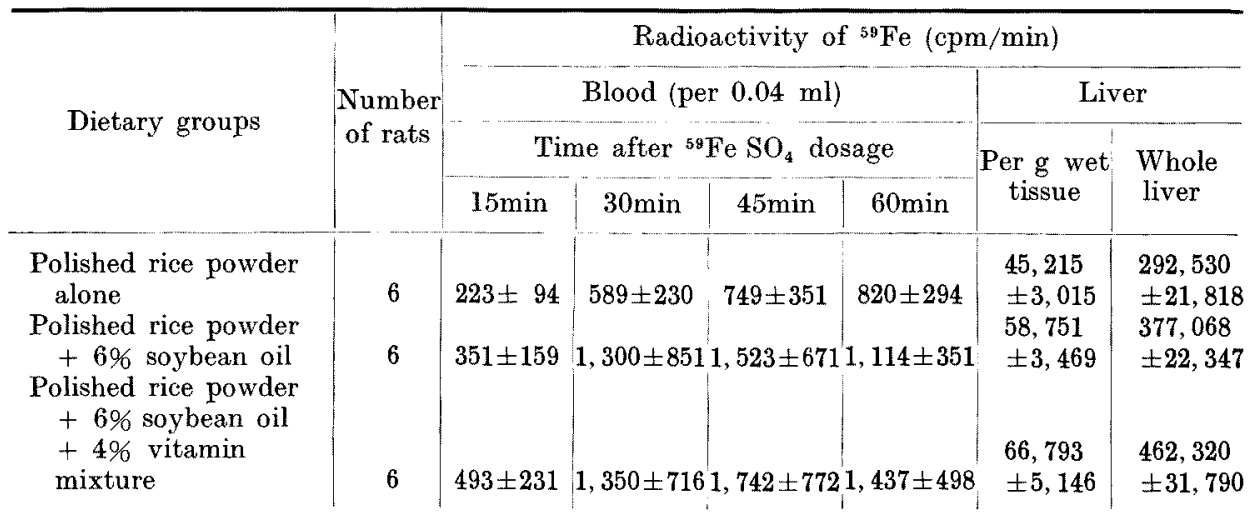

\section{Experiment III}

The experiment was performed in order to examine the effect of various concentrations of soybean oil added to the basal diet on iron absorption.

As shown in Fig. 2 and Table 3, the ${ }^{59} \mathrm{Fe}$ activity in the blood 30,45 and 60 minutes after the introduction of ${ }^{59} \mathrm{Fe}$ was significantly higher in rats fed on the diets containing 3 to $12 \%$ soybean oil, than in those fed on a diet consisting of polished rice powder $+4 \%$ vitamin mixture. However, no significant difference in radioactivity of ${ }^{59} \mathrm{Fe}$ in the blood was observed among rats of dietary groups supplemented with soybean oil at concentrations of 3,6 and $12 \%$. 


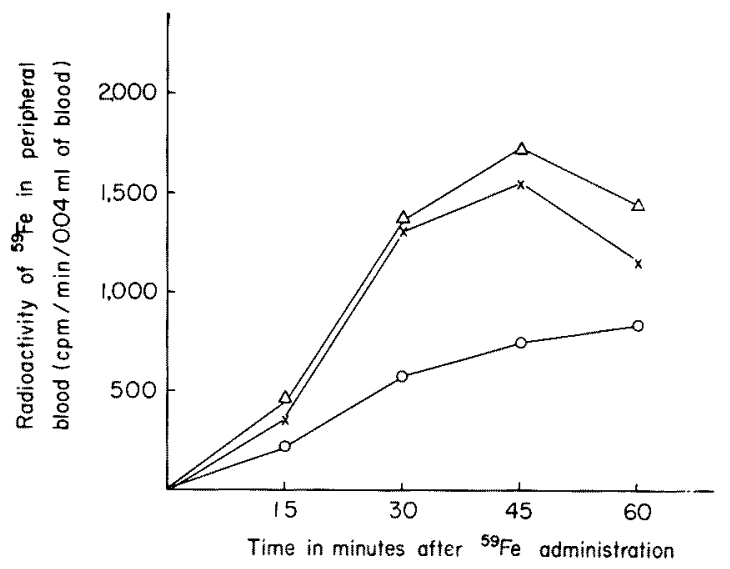

Fig. 1. Radioactivity of ${ }^{59} \mathrm{Fe}$ in peripheral blood of rats in Experiment II.

- Polished rice powder alone

$\times-$ Polished rice powder $+6 \%$ soybean oil

$\triangle \triangle_{\triangle}$ Polished rice powder $+6 \%$ soybean oil $+4 \%$ vitamin mixture

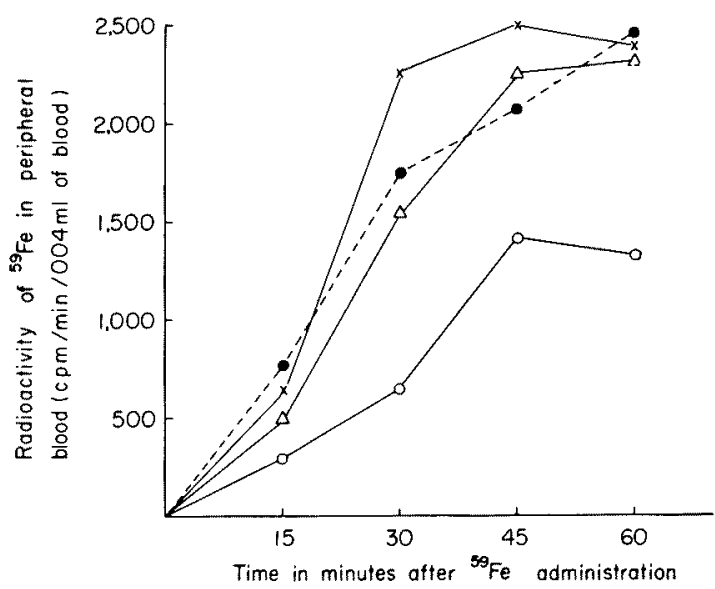

Fig. 2. Radioactivity of ${ }^{59} \mathrm{Fe}$ in peripheral blood of rats in Experiment III.

Polished rice powder $+4 \%$ vitamin mixture

$\times$ - Polished rice powder $+3 \%$ soybean oil $+4 \%$ vitamin mixture

$\triangle \triangle_{\triangle}$ Polished rice powder $+6 \%$ soybean oil $+4 \%$ vitamin mixture

- - Polished rice powder $+12 \%$ soybean oil $+4 \%$ vitamin mixture

The radioactivity of ${ }^{59} \mathrm{Fe}$ in the liver 120 minutes after iron introduction showed higher activity in the dietary groups containing 3 to $12 \%$ soybean oil, than that in the basic diet group. However, there was no significant difference in the ${ }^{59} \mathrm{Fe}$ contents in the liver among rats of the dietary groups of 3,6 and $12 \%$ soybean oil. 
M. Hirooka et al.

TABLE 3. Radioactivity of ${ }^{59}$ Fe in the peripheral blood and the liver 120 minutes after ${ }^{59} \mathrm{FeSO}_{4}$ dosage in Experiment $\mathrm{III}$

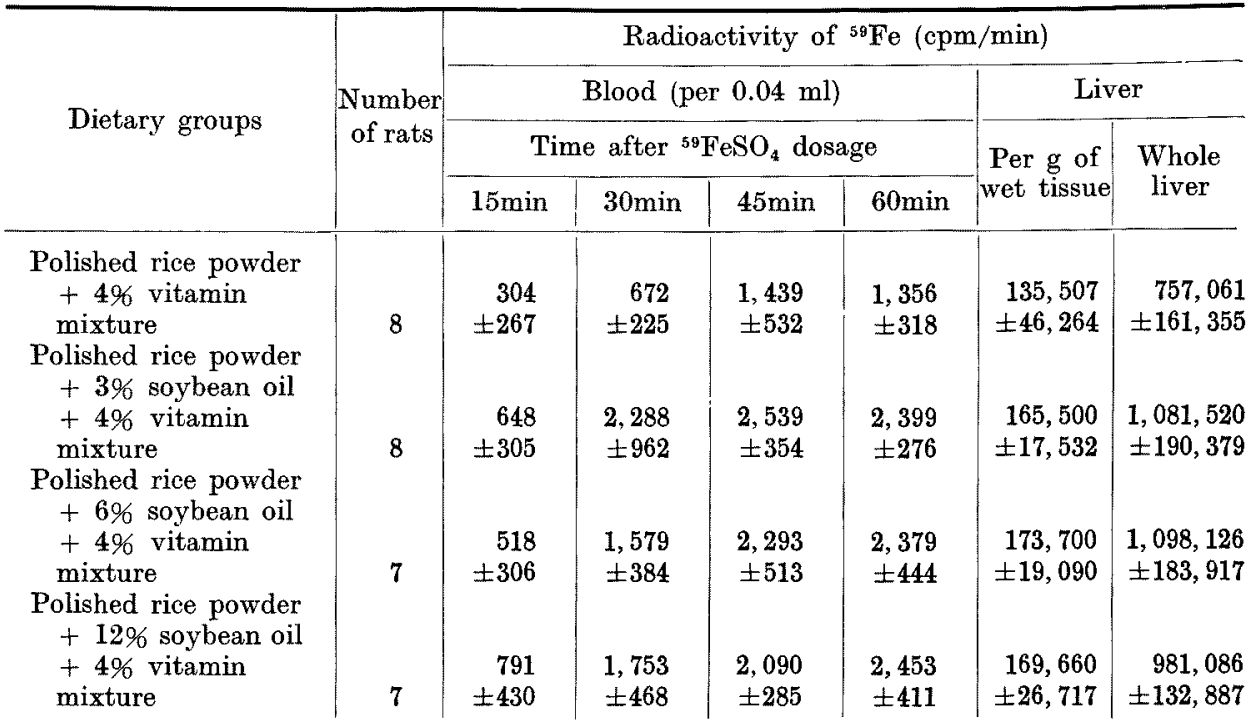

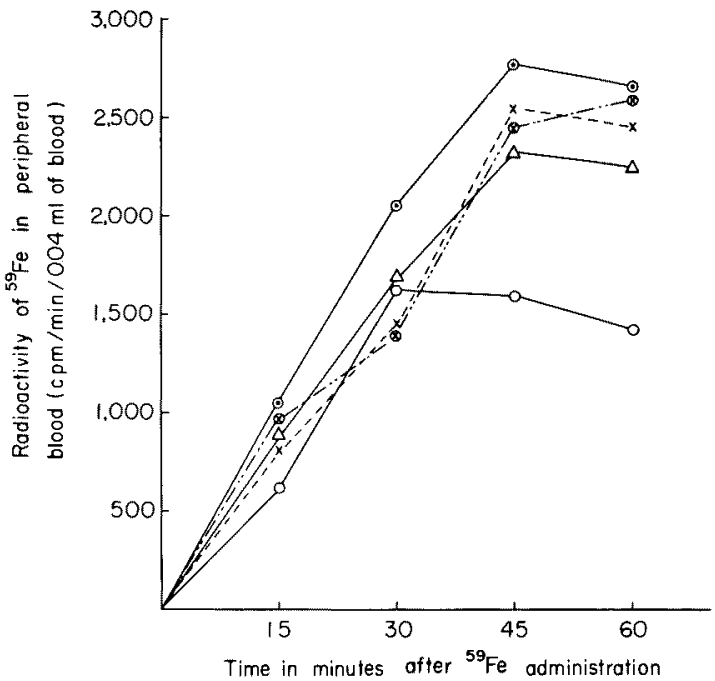

Fig. 3. Radivactivity of ${ }^{59} \mathrm{Fe}$ in peripheral blood of rats in Experiment IV.

Polished rice powder $+4 \%$ vitamin mixture

$\Delta \longrightarrow \triangle$ Polished rice powder $+6 \%$ soybean oil $+4 \%$ vitamin mixture

$x-\cdots x$ Polished rice powder $+18 \%$ casein $+4 \%$ vitamin mixture

- - Polished rice powder $+6 \%$ soybean oil $+18 \%$ casein $+4 \%$ vitamin mixture

$\odot$ Oriental solid foods for propagation of rats 


\section{Experiment $I V$}

The experiment was designed in order to compare the effect of the diet supplemented with $6 \%$ soybean oil on iron absorption with that of supplementation of $18 \%$ casein.

The activity of ${ }^{59} \mathrm{Fe}$ in the blood of rats fed the diet containing $6 \%$ soybean oil, $18 \%$ casein, $6 \%$ soybean oil $+18 \%$ casein, or Oriental solid foods for propagation of rats was higher than that in rats fed on the basic diet consisting of polished rice powder $+4 \%$ vitamin mixture. However, there were statistically significant differences in ${ }^{59} \mathrm{Fe}$ uptake in the liver among the $6 \%$ soybean oil group, the $6 \%$ soybean oil $+18 \%$ casein group and the group of $18 \%$ casein alone, showing a higher activity in the first two groups.

The highest values of ${ }^{59} \mathrm{Fe}$ uptake in the liver were found in rats fed the Oriental solid foods for propagation of rats, which contains crude protein $26.55 \%$, crude fat $6.1 \%$ and various kinds of vitamin, as shown in Table 4.

TABLE 4. Radioactivity of ${ }^{59} \mathrm{Fe}$ in the peripheral blood and the liver 120 minutes after ${ }^{59} \mathrm{FeSO}_{4}$ dosage in Experiment $\mathrm{IV}$

\begin{tabular}{|c|c|c|c|c|c|c|c|}
\hline \multirow{4}{*}{ Dietary groups } & \multirow{4}{*}{$\begin{array}{l}\text { Number } \\
\text { of rats }\end{array}$} & \multicolumn{6}{|c|}{ Radioactivity of ${ }^{59} \mathrm{Fe}(\mathrm{cpm} / \mathrm{min})$} \\
\hline & & \multicolumn{4}{|c|}{ Blood $(0.04 \mathrm{ml})$} & \multicolumn{2}{|c|}{ Liver } \\
\hline & & \multicolumn{4}{|c|}{ Time after ${ }^{59} \mathrm{FeSO}_{4}$ dosage } & \multirow{2}{*}{$\begin{array}{c}\text { Per } g \text { of } \\
\text { wet tissue }\end{array}$} & \multirow{2}{*}{$\begin{array}{l}\text { Whole } \\
\text { liver }\end{array}$} \\
\hline & & $15 \mathrm{~min}$ & $30 \mathrm{~min}$ & $45 \mathrm{~min}$ & $60 \mathrm{~min}$ & & \\
\hline $\begin{array}{l}\text { Polished rice powder } \\
+4 \% \text { vitamin } \\
\text { mixture }\end{array}$ & 5 & $\begin{array}{r}648 \\
\pm 148\end{array}$ & $\begin{array}{r}1,678 \\
\pm 388\end{array}$ & $\begin{array}{r}1,632 \\
\pm 250\end{array}$ & $\begin{array}{r}1,419 \\
\pm 256\end{array}$ & $\begin{array}{r}65,966 \\
\pm \quad 7,236\end{array}$ & $\begin{array}{r}478,661 \\
\pm \quad 97,901\end{array}$ \\
\hline $\begin{array}{l}\text { Polished rice powder } \\
\quad+6 \% \text { soybean oil } \\
+4 \% \text { vitamin } \\
\text { mixture }\end{array}$ & 5 & $\begin{array}{r}900 \\
\pm 97\end{array}$ & $\begin{array}{r}1,643 \\
\pm 209\end{array}$ & $\begin{array}{r}2,323 \\
\pm 623\end{array}$ & $\begin{array}{r}2,238 \\
\pm 400\end{array}$ & $\begin{array}{r}161,132 \\
\pm 19,751\end{array}$ & $\begin{array}{l}1,245,849 \\
\pm 178,704\end{array}$ \\
\hline $\begin{array}{l}\text { Polished rice powder } \\
+18 \% \text { casein }+4 \% \\
\text { vitamin mixture }\end{array}$ & 6 & $\begin{array}{r}866 \\
\pm 153\end{array}$ & $\begin{array}{r}1,476 \\
\pm 229\end{array}$ & $\begin{array}{r}2,507 \\
\pm 356\end{array}$ & $\begin{array}{r}2,420 \\
\pm 236\end{array}$ & $\begin{array}{r}84,467 \\
\pm \quad 7,146\end{array}$ & $\begin{array}{r}677,943 \\
+\quad 43,027\end{array}$ \\
\hline $\begin{array}{l}\text { Polished rice powder } \\
\quad+6 \% \text { soybean oil } \\
+18 \% \text { casein }+4 \% \\
\text { vitamin mixture }\end{array}$ & 6 & $\begin{array}{r}903 \\
\pm 252\end{array}$ & $\begin{array}{r}1,447 \\
\pm 216\end{array}$ & $\begin{array}{r}2,446 \\
\pm 330\end{array}$ & $\begin{array}{r}2,563 \\
\pm 358\end{array}$ & $\begin{array}{r}156,515 \\
\pm 17,894\end{array}$ & $\begin{array}{l}1,261,430 \\
\pm 145,400\end{array}$ \\
\hline $\begin{array}{l}\text { Oriental solid foods } \\
\text { for propagation of } \\
\text { rats }\end{array}$ & 6 & $\begin{array}{r}998 \\
\pm 229\end{array}$ & $\begin{array}{r}2,057 \\
\pm 721\end{array}$ & $\begin{array}{r}2,723 \\
\pm 625\end{array}$ & $\begin{array}{r}2,664 \\
\pm 380\end{array}$ & $\begin{array}{r}206,650 \\
\pm 26,110\end{array}$ & $\begin{array}{r}1,777,892 \\
\pm 263,348\end{array}$ \\
\hline
\end{tabular}

\section{Comment}

In Experiment I, hepatic non-hemin iron was estimated on rats fed on diets of various compositions for 2 weeks.

This was the reason why it was generally reported that a decrease in iron store in the body was a factor contributing to increased iron absorption, ${ }^{19-24}$ and that iron was stored mainly in the liver and bone marrow. ${ }^{25}$ 
The result of Experiment I revealed that there was no statistically significant difference in hepatic iron among rats of various dietary groups, showing that the results of iron absorption tests obtained in Experiments II-IV were not influenced by iron store in the body.

In the present experiments, polished rice powder, which is high in phytin and phosphorus and low in calcium, was used as a basic diet for rats. It has been demonstrated that the diet with a low calcium, high phosphorus and high phytic acid content may suppress iron absorption. ${ }^{7,9-11}$ Actually, the results of Experiments II-IV indicated that iron absorption was apparently low in the basic diet group consisting of polished rice powder or polished rice powder $+4 \%$ vitamin mixture as compared with thcse in other dietary groups.

The result of Experiment II indicated that iron absorption was apparently enhanced when the rats were fed on the basic diet supplemented with $6 \%$ soybean oil. In Experiment III, there was no significant difference in the intestinal iron absorption among the supplementations of 3,6 and $12 \%$ soybean oil, suggesting that the amount of soybean oil supplemented to the basic diet is probably not an important factor in increasing iron absorption. And further, it was worthy of special notice that, as observed in Experiment IV, iron absorption in the $6 \%$ soybean oil group was increased to the levels as seen in the $18 \%$ casein group.

It has been well known that iron absorption is influenced by dietary components. Ascorbic acid ${ }^{1-3}$ has been shown to increase iron absorption, and protein $^{4,5}$ is known also to influence iron absorption in rats. Klavins et al..$^{4,5}$ found that protein content of approximately 15 to $18 \%$ in diet was necessary for adequate iron absorption, and that when smaller amounts of protein were given, iron absorption was impaired. Kroe et $a l .{ }^{6}$ reported, in a series of experiments which were done by introducing single amino acids and ${ }^{59} \mathrm{Fe}$ into isolated loops of small intestine of rats, that all amino acids such as histidine, asparagin, glutamic acid, glutamine, ethionine and serine caused increase in the serum iron and iron deposition in the liver. Further, the same authors ${ }^{13}$ studied the interrelation of these amino acids and $\mathrm{pH}$ of intestinal lumen to the intestinal iron absorption and confirmed that the maximal intestinal iron absorption did occur in a $\mathrm{pH}$ range of $2.0-3.5$ of the intestinal lumen.

Neal and Pearson ${ }^{12}$ reported that contrary to previous reports there was no increase in intestinal iron absorption in vitamin $B_{6}$ deficient rats under physiological conditions, and that supplementation of the vitamin to the deficient animals rather resulted in a greatly enhanced iron absorption.

Besides the dietary factors mentioned above, other factors such as rapid changes of diet or starvation ${ }^{26}$ have been shown to influence the amount of iron absorbed. With regard to the influence of dietary fat on intestinal iron absorption, however, a very few reports have been published without any definite conclusion.

Kaufman et al. ${ }^{14}$ demonstrated that iron absorption was increased when rats were fed on the diet containing $10 \%$ casein and $60 \%$ lard, and supposed that changes in the pancreas caused by high fat diet might be responsible for the increase 
in iron absorption. However, from the investigations concerning the influence of dietary protein on iron absorption in rats, they ${ }^{5}$ later stated that increased iron absorption observed in feeding with high fat diet might indicate a significant role of dietary fat in iron absorption.

Sorensen ${ }^{15}$ found that in iron deficient rats, intestinal iron absorption was higher when ${ }^{59} \mathrm{Fe}(5 \mu \mathrm{c} / \mu \mathrm{g})$ was administered together with the test meal consisting of carbohydrate $(0.5 \mathrm{~g}$ glucose) or fat ( $1 \mathrm{~g}$ of $35 \%$ cream), as compared with cases where iron was given with protein. In non-deficient rats, too, the same results were obtained, although iron absorbed was considerably less in amount than that in iron-deficient rats.

Amano ${ }^{16,17}$ carried out a histological study on the intestinal absorption of iron in rats after single or repeated oral administration of fatty acid-iron and demonstrated that iron absorption might be accelerated when fat was present in the diet.

Recently, there has been increasing interest about the role of pancreatic exocrine secretion in iron absorption. A number of investigators ${ }^{28-32}$ have published data suggesting that pancreatic secretion depresses iron absorption, while lack of pancreatic secretion permits increased iron absorption. The result, however, is still controversial. ${ }^{33,34}$

A high fat and low protein diet containing $60 \%$ of lard and $10 \%$ of casein was used in Kaufman et al. ' $^{14}$ experiments on rats, and they ${ }^{14}$ stated that such a high fat diet has some possibility to give rise to pancreatic damage and to enhance iron absorption.

However, in the present experiments, soybean oil, which is of vegetable origin and rich in unsaturated fatty acids, was used in low concentrations of 3 to $12 \%$. Because such low levels of soybean oil content in diet would not induce pancreatic damage, soybean oil itself is to be considered to have a specific influence on iron absorption in rats.

\section{References}

1) Moore, C.V. \& Dubach, R. Observation on the absorption of iron from foods tagged with radioiron. Tr. Assoc. Amer. Physicians, 1951, 64, 245-256.

2) Utilization of iron compounds in enriched bread. 1955. 13, 165-167.

3) Steinkamp, R., Dubach, R. \& Moore, C.V. Studies in iron transportation and metabolism. Arch. intern Med., 1955, 95, 181-193.

4) Klavins, J.V., Kinney, T.D. \& Kaufman, N. Iron absorption in rats fed a protein free diet. Amer. J. Path., 1959, 35, 690.

5) Klavins, J.V., Kinney, T.D. \& Kaufman, N. The influence of dietary protein on iron absorption. Brit. J. exp. Path., J962, 43, 172-180.

6) Kroe, D., Kinney, T.D., Kaufman, N. \& Klavins, J.V. The influence of amino acids on iron ahsorption. Blood, 1963, 21, 546-551.

7) Effect of phytate on iron absorption. Nutr. Rev. 1967, 25, 218-222.

8) Cowan, J.W., Esfahaji, M., Salji, J.P. \& Azzam, S.A. Effect of phytate on iron absorption in the rat. $J$. Nutr. 1966, 90, 423-427.

9) Hussain, R. \& Patwardhan, V.N. The influence of phytate on the absorption of iron. Indian J. med. Res., 1959, 47, 676-682.

10) Apte, S.V. \& Venkatachalama, P.S. The influence of dietary calcium on absorp- 
tion of iron. Indian J. med. Res., 1964, 52, 213-218.

11) Sathe, V. \& Krishnamurthy, K. Phytic acid and absorption of iron. Indian $J$. med. Res., 1953, 41, 453-457.

12) Neal, R.A. \& Pearson, W.N. Effect of pyridoxine deficiency on iron absorption in the rat. J. Nutr. $1962, \mathbf{7 8}, 215-218$.

13) Kroe, D.J., Kaufman, N., Klavins, J.V. \& Kinney, T.D. Interrelation of aminoacids and $\mathrm{pH}$ on intestinal iron absorption. Amer. J. Physiol., 1966, 211, 414-418.

14) Kaufman, N., Klavins, J.V. \& Kinney, T.D. Excessive iron absorption in rats fed low protein, high-fat diets. Lab. Invest., 1948, 7, 369-376.

15) Sørensen, F.W. Studies on iron absorption II. Experiments with iron-deficient and non-deficient rats. Acta med. scand., 1965, 178, 385-392.

16) Amano, T. Absorption of fatty acid iron from the intestine $I$. Absorption of iron after a single oral administration of fatty acid-iron. Acta med. Okayama, 1963, 17, $139-146$.

17) Amano, T. Absorption of fatty acid-iron from the intestine II. Absorption of iron after repeated oral administration of fatty acid-iron and intravenous injection of colloidal fatty acid-iron. Acta med. Okayama, 1963. 17, 147-152.

18) Yoshino, Y. Studies on iron in body fluid : Microdetermination of non-hemin iron in tissues with quinaldinic acid. Nippon Ika Daig. Z. (Jap.), 1952, 19, 395-399.

19) Hepatic iron stores and iron absorption. Nutr. Rev. 1964, 22, 214-216.

20) Pirzio-Brioli, G. \& Finch, C.A. Iron absorption III. The influence of iron stores on iron absorption in the normal subject. $J$. Lab. clin. Med., 1960, 55, 216-220.

21) Hahn, P.F., Bale, W.F., Ross, J.F., Balfour, W.M. \& Whipple, G.H. Radioactive iron absorption by gastro-intestinal tract. Influence of anemia, anoxia and antecedent feeding. Distribution in growing dogs. J. exp. Med., 1943, 78, 169-188.

22) Weintraub, L.R., Conrad, M.E., Crosby, W.H. \& Foy, A.L. The role of hepatic iron stores in the control of iron absorption. J. clin. Invest., 1964, 43, 40-44.

23) Mendel, G.A., Weiler, R.J. \& Mangalic, A. Studies on iron absorption II. The absorp tion of iron in experimental anemias of diverse etiology. Blood, 1963, 22, 450-458.

24) Bannermann, B.M., O'Brien, J.R.P. \& Witts, J.I. Studies in iron metabolism IV. Iron absorption in experimental iron deficiency. Blood, 1962, 20, 532-546.

25) Iron storage in bone marrow. Nutr. Rev. 1963, 31, 329-331.

26) Iron absorption and diet. Nutr. Rev. 1964, 22, 306-309.

27) Higginson, J., Grady, H. \& Huntley, C. The effects of different diet on iron absorption. Lab. Invest., 1963, 12, 1260-1269.

28) Davis, A.E. Relationship of disturbed pancreatic function to haemosiderosis. Lancet, 1961, 2, 749-750.

29) Sephton-Smith, R. Iron absorption in cystic fibrosis. Brit. med.J., 1964, 1, 608-609.

30) Tonz, O., Weiss, S., Strahm, H.W. \& Rossi, E. Iron absorption in cystic fibrosis. Lancet, 1965, 1, 1096-1099.

31) Davis, A.E. \& Badenoch, J. Iron absorption in pancreatic disease. Lancet, 1962, 2, 6-8.

32) Davis, A.E. \& Biggs, J.C. The pancreas and iron absorption: Current views. Amer. J. dig. Iis., 1967, 12, 293-302.

33) Murray, M.J. \& Stein, N. Does the pancreas influence iron absorption? A critical review of information to date. Gastroenterology, 1966, 51, 694-700.

34) Balcerzak, S.P., Peternel, W.W.\& Henle, E.W. Iron absorption in chronic pancreatitis. Gastroenterology, 1967, 53, 257-264. 